\title{
Homogeneous Mercury Oxidation under Simulated Flue Gas of Oxy-coal Combustion
}

\author{
Achariya Suriyawong $^{1,2, *}$ and Pratim Biswas ${ }^{3}$ \\ 1 Department of Environmental Engineering, Faculty of Engineering, Chulalongkorn University, Bangkok \\ 10330, Thailand \\ 2 National Center of Excellence for Environmental and Hazardous Waste Management, \\ Chulalongkorn University, Bangkok 10330, Thailand \\ 3 Aerosol and Air Quality Research Laboratory, Department of Energy, Environmental and Chemical \\ Engineering, Box 1180, Washington University in St. Louis, St. Louis, MO 63130, USA \\ *E-mail: Achariya.S@eng.chula.ac.th
}

\begin{abstract}
This study investigated the effects of oxy-coal combustion on $\mathrm{Hg}$-oxidation by $\mathrm{HCl}$ using simulated flue gas. Experiments were conducted with different carrier gases that one might find in oxy-coal combustion and conventional coal combustion. The extents of $\mathrm{Hg}$-oxidation in pure $\mathrm{CO}_{2}$, pure $\mathrm{N}_{2}$ and air were also studied for comparison. Our experimental results demonstrated that $\mathrm{CO}_{2}$ weakly assisted $\mathrm{Hg}$-oxidation by $\mathrm{HCl}$; however, its significance was outweighed by the presence of $\mathrm{O}_{2}$. For all carrier gases, the presence of $\mathrm{NO}$ or $\mathrm{H}_{2} \mathrm{O}$ inhibited $\mathrm{Hg}$-oxidation. The inhibitory effects strongly depended on concentrations of NO, but not moisture content. The synergistic inhibitory effects were shown when both $\mathrm{NO}$ and $\mathrm{H}_{2} \mathrm{O}$ were present together. The extents of $\mathrm{Hg}$-oxidation were not significantly different for $\mathrm{O}_{2}-\mathrm{N}_{2}, \mathrm{O}_{2}-\mathrm{N}_{2}-\mathrm{CO}_{2}$ and $\mathrm{O}_{2}-\mathrm{CO}_{2}$ gas mixtures for all conditions investigated in this study.
\end{abstract}

Keywords: Coal combustion, mercury emission, oxy-coal combustion, mercury speciation.

ENGINEERING JOURNAL Volume 17 Issue 4

Received 9 December 2012

Accepted 27 February 2013

Published 1 October 2013

Online at http://www.engj.org/

DOI:10.4186/ej.2013.17.4.35 


\section{Introduction}

Global climate change is now an issue of great concern and strongly exacerbated by the rising levels of carbon dioxide $\left(\mathrm{CO}_{2}\right)$ in the atmosphere due to human activities, such as burning of fossil fuels and deforestation. Coal, the cheapest and most abundant fossil fuel, is currently one of the most widely used energy sources globally, and it will continue to be dominant for many decades. Capturing $\mathrm{CO}_{2}$ from coal combustion exhaust has been receiving significant attention; however, the volume fraction of $\mathrm{CO}_{2}$ in a conventional coal combustion system (with air) ranges between $13 \%-15 \%$, making it difficult to costeffectively design these systems. One approach to overcome the limitation of low $\mathrm{CO}_{2}$ concentration in the exhaust is oxy-coal combustion, where coal is combusted in an oxygen-enriched stream (with nitrogen removed) with recycled exhaust gas as a diluent. At steady state operation, such a configuration would result in a $\mathrm{CO}_{2}$ concentration of $95 \%$ in the exhaust, making it more feasible to capture [1-4]. Many studies have reported other advantages of this combustion system, including reduction of volume of flue gas, elimination of thermal $\mathrm{NO}_{\mathrm{x}}$, and potential for increasing boiler thermal efficiency $[5,6]$.

While the benefits of the oxy-coal combustion are clear, changing the composition of the combustion gas mixture may have numerous effects on the pollutants associated with coal combustion, and subsequently the performance of pollution control devices. In our laboratory, we have previously investigated the effects oxy-coal combustion on the formation of submicrometer-sized particles and their capture by an electrostatic precipitator (ESP) $[7,8]$. The submicrometer particle size distribution was shifted toward a smaller size when $\mathrm{N}_{2}$ in air was replaced by $\mathrm{CO}_{2}$ [7], and penetration of the particle through an ESP was 1-2 orders of magnitude higher in $\mathrm{O}_{2}-\mathrm{CO}_{2}$ environments than in $\mathrm{O}_{2}-\mathrm{N}_{2}$ environments [8]. Croiset and Thambimuthu (2001)[9] and Lui and Okazaki (2003)[6] observed a significant reduction in $\mathrm{NO}_{\mathrm{X}}$ emissions from oxy-coal combustion. Croiset and Thambimuthu (2001)[9] also reported a decrease in the conversion of sulfur to sulfur dioxide $\left(\mathrm{SO}_{2}\right)$ from $91 \%$ to $75 \%$ when $\mathrm{N}_{2}$ was replaced by $\mathrm{CO}_{2}$, and to $64 \%$ when $\mathrm{CO}_{2}$ came from the recycled flue gas.

Mercury is one of the most toxic environmental pollutants and highly bio-concentrated metals in the human food chain. Coal-fired utility plants are the largest anthropogenic source of mercury emission in the United States [10]. On March 15, 2005, the United States Environmental Protection Agency (US EPA) issued the Clean Air Mercury Rule (CAMR) to regulate $\mathrm{Hg}$ emissions from coal-fired power plants using a cap-and-trade approach. Mercury emission from coal-fired power plants would be reduced from 48 tons per year to 15 tons per year, a reduction of nearly $70 \%$ (US EPA, 2005). However, many states and organizations challenged the CAMR. On February 8, 2008, the U.S. Court of Appeals for the District of Columbia Circuit vacated the CAMR, and required the US EPA to reconsider the Mercury Rule (Edison Electric Institute, 2008). It is expected that mercury regulation will become more stringent and the power plants will be required to install $\mathrm{Hg}$ control devices. As a result, extensive research and development are in progress for control methodologies.

Like other pollutants, mercury capture methodology relies primarily on the knowledge of mercury speciation in flue gas. Mercury exists in three forms in coal-combustion flue gas: elemental mercury $\left(\mathrm{Hg}^{0}\right)$, oxidized $\left(\mathrm{Hg}^{2+}\right)$, and particulate-bound $\left(\mathrm{Hg}_{(\mathrm{p})}\right)$. During combustion, mercury is liberated from coal as $\mathrm{Hg}^{0}$. As the flue gas cools, some of the $\mathrm{Hg}^{0}$ is oxidized - presumably to $\mathrm{HgCl}_{2}$ due to the presence of chlorine in coal. While $\mathrm{Hg}^{0}$ is insoluble in water and difficult to capture, $\mathrm{HgCl}_{2}$ is water-soluble and readily captured in the pollution control devices, such as scrubbers. Several factors play an important role in the fate of mercury emission, including chlorine species, carbon monoxide $(\mathrm{CO})$, moisture $\left(\mathrm{H}_{2} \mathrm{O}\right)$, sulfur dioxide $\left(\mathrm{SO}_{2}\right)$, and nitrous oxide (NO). Chlorine species have been regarded as the key factor affecting mercury oxidation. Many studies indicated a strong correlation between chlorine content in coal and oxidized mercury in flue gas; high chlorine content typically resulted in more oxidized mercury in flue gas [11-14]. Extensive efforts have also been made in unraveling the reaction mechanism for homogeneous mercury oxidation through a sequence of elementary reactions. To date, it has been widely accepted that $\mathrm{Hg}^{0}$ was first oxidized into the intermediate $\mathrm{HgCl}$, which further reacted with chlorinating species to form thermodynamically stable $\mathrm{HgCl}_{2}$ [15-17]. The dominant mercury oxidizing species is atomic chlorine $(\mathrm{Cl})$ and to a lesser extent of other chlorinating species, such as molecular chlorine $\left(\mathrm{Cl}_{2}\right)$, hypochlorite $(\mathrm{HOCl})$ and hydrogen chloride $(\mathrm{HCl})$ $[11,15,18,19]$. Other constituents in flue gas and their concentrations also affect mercury oxidation. CO promotes mercury oxidation, while moisture and $\mathrm{SO}_{2}$ impede the oxidation [19-23]. NO can either inhibit or promote mercury oxidation and $\mathrm{HgCl}_{2}$ formation, depending on its concentration $[18,19]$.

In oxy-coal combustion, the constituents in flue gas are different than those generated in conventional (coal-air) combustion. In this context, the fate of mercury emission may be significantly affected. A few 
research reported the fate of mercury under oxy-coal combustion [24, 25]. Font et al. (2012)[24] investigated fate of mercury and other trace elements in a coal fluidized bed oxy combustion pilot plant and reported that $7.5 \%$ of $\mathrm{Hg}$ existed in gaseous form and very high proportion was found in pollutant control devices, including cyclone and bag-filters. Wang et al. (2013)[25] compared speciation of mercury presence during air-coal and oxy-coal combustion. They reported that more $\mathrm{Hg}^{0}$ and $\mathrm{Hg}^{2+}$ were released into gasphase when coal was combusted in $\mathrm{O}_{2}-\mathrm{CO}_{2}$ environment than that in air at $800^{\circ} \mathrm{C}$; however, when coal was combusted at $850^{\circ} \mathrm{C}$, less $\mathrm{Hg}^{0}$ and $\mathrm{Hg}^{2+}$ were found in $\mathrm{O}_{2}-\mathrm{CO}_{2}$ combustion environment than that in air. Coal-combustion is a complex process and several factors play important roles on the fate of mercury. Since selecting appropriate mercury control methodology relies primarily on the knowledge of mercury speciation in flue gas, systematically identifying the effects of influencing factors should be developed. This study aimed to establish the understanding of mercury oxidation under oxy-coal combustion using simulated flue gas. The influences of $\mathrm{NO}$ and $\mathrm{H}_{2} \mathrm{O}$ on the oxidation are also reported. The results presented here will be beneficial to the current development of mercury control methodology, and will help to facilitate the transition of the technology when it is applied in oxy-coal combustion.

\section{Experimental and Methods}

\subsection{Test Plan}

The experimental plan is outlined in Table 1. Set I experiments evaluated the effects of carrier gases on $\mathrm{Hg}$ oxidation by $\mathrm{HCl}$. Experiments were conducted at different temperatures, ranging between 500 to $900^{\circ} \mathrm{C}$. The gas mixtures examined were chosen to mimic gas mixtures that one might find in oxy-coal and conventional (coal-air) combustions. Pure $\mathrm{CO}_{2}$, pure $\mathrm{N}_{2}$ and air were also studied for comparison. Set II and Set III experiments were designed to independently evaluate the roles of $\mathrm{H}_{2} \mathrm{O}$ and $\mathrm{NO}$ on the extent of $\mathrm{Hg}$ oxidation by $\mathrm{HCl}$ in different carrier gas. In these sets of experiments, concentrations of $\mathrm{NO}$ and $\mathrm{H}_{2} \mathrm{O}$ were chosen based on the values typically reported in coal combustion systems. The concentration of $\mathrm{HCl}$ was held constant at $100 \mathrm{ppm}_{\mathrm{v}}$, while concentrations of $\mathrm{NO}$ and $\mathrm{H}_{2} \mathrm{O}$ were varied between $40-200 \mathrm{ppm}_{\mathrm{v}}$ and $0-20 \%$ by volume, respectively. Set IV experiments were conducted to examine the combined effects of $\mathrm{H}_{2} \mathrm{O}$ and $\mathrm{NO}$ on $\mathrm{Hg}$ oxidation by $\mathrm{HCl}$. In this set of experiments, the concentration of $\mathrm{HCl}$ and $\mathrm{H}_{2} \mathrm{O}$ were held constant at $100 \mathrm{ppm}_{\mathrm{v}}$ and $7 \%$ by volume, respectively, while the selected concentrations of NO were 40 to $100 \mathrm{ppm}_{\mathrm{v}}$.

Table 1. Summary of the experiments performed.

\begin{tabular}{|c|c|c|c|c|c|c|c|c|}
\hline \multirow[b]{2}{*}{ Set } & \multirow[b]{2}{*}{ Objective } & \multicolumn{7}{|c|}{ Gas Composition } \\
\hline & & $\begin{array}{l}\mathbf{N}_{2} \\
(\%)\end{array}$ & $\begin{array}{l}\mathrm{O}_{2} \\
(\%) \\
\end{array}$ & $\begin{array}{l}\mathrm{CO}_{2} \\
(\%)\end{array}$ & $\begin{array}{l}\mathrm{H}_{2} \mathrm{O} \\
(\%)\end{array}$ & $\begin{array}{c}\mathrm{NO} \\
\left(\mathrm{ppm}_{\mathrm{v}}\right)\end{array}$ & $\begin{array}{c}\mathrm{Hg} \\
\left(\mu \mathrm{g} / \mathrm{m}^{3}\right)\end{array}$ & $\begin{aligned} \mathrm{HCl} \\
\left(\mathrm{ppm}_{\mathrm{v}}\right)\end{aligned}$ \\
\hline 1 & $\begin{array}{l}\text { Investigate the role of carrier } \\
\text { gas on } \mathrm{Hg} \text {-oxidation by } \mathrm{HCl}\end{array}$ & $\begin{array}{c}100 \\
- \\
90 \\
- \\
- \\
79\end{array}$ & $\begin{array}{l}- \\
- \\
10 \\
10 \\
10 \\
21\end{array}$ & $\begin{array}{c}- \\
100 \\
- \\
90 \\
14 \\
-\end{array}$ & $\begin{array}{l}- \\
- \\
- \\
- \\
-\end{array}$ & $\begin{array}{l}- \\
- \\
-\end{array}$ & 20 & 100 \\
\hline 2 & $\begin{array}{l}\text { Evaluate the effects of } \mathrm{H}_{2} \mathrm{O} \text { on } \\
\mathrm{Hg} \text {-oxidation by } \mathrm{HCl} \text { in different } \\
\text { carrier gas }\end{array}$ & $\begin{array}{c}\text { balance } \\
- \\
\text { balance } \\
- \\
\text { balance } \\
\text { balance } \\
\end{array}$ & $\begin{array}{c}- \\
- \\
10 \\
10 \\
10 \\
21 \\
\end{array}$ & $\begin{array}{c}- \\
\text { balance } \\
- \\
\text { balance } \\
14 \\
- \\
\end{array}$ & $0-20$ & $\begin{array}{l}- \\
- \\
- \\
\end{array}$ & 20 & 100 \\
\hline 3 & $\begin{array}{l}\text { Evaluate the effects of } \mathrm{NO} \text { on } \\
\text { Hg-oxidation by } \mathrm{HCl} \text { in different } \\
\text { carrier gas }\end{array}$ & $\begin{array}{c}\text { balance } \\
- \\
\text { balance } \\
- \\
\text { balance } \\
\text { balance }\end{array}$ & $\begin{array}{l}- \\
- \\
10 \\
10 \\
10 \\
21\end{array}$ & $\begin{array}{c}- \\
\text { balance } \\
- \\
\text { balance } \\
14 \\
-\end{array}$ & $\left.\begin{array}{l}- \\
- \\
- \\
- \\
-\end{array}\right)$ & $40-400$ & 20 & 100 \\
\hline 4 & $\begin{array}{l}\text { Determine the combined effects } \\
\text { of } \mathrm{NO} \text { and } \mathrm{H}_{2} \mathrm{O} \text { on } \mathrm{Hg} \text {-oxidation } \\
\text { in different carrier gas }\end{array}$ & $\begin{array}{c}\text { balance } \\
- \\
\text { balance } \\
- \\
\text { balance } \\
\text { balance }\end{array}$ & $\begin{array}{l}- \\
- \\
10 \\
10 \\
10 \\
21 \\
\end{array}$ & $\begin{array}{c}- \\
\text { balance } \\
- \\
\text { balance } \\
14 \\
-\end{array}$ & 7,20 & 40,100 & 20 & 100 \\
\hline
\end{tabular}




\subsection{Experimental Setup}

The experimental setup, shown in Fig. 1, consisted of inlet manifolds, where $\mathrm{Hg}$, carrier gases and other gases were introduced, a quartz tube reactor $(50 \mathrm{~cm}$ long with an inner diameter of $2.54 \mathrm{~cm}$ ), a furnace $\left(1100^{\circ} \mathrm{C}\right.$ laboratory tube furnace, Lindberg) to simulate a high temperature environment, and a mercury sampling train. Mercury vapor was introduced into the system by passing particle-free $\mathrm{CO}_{2}, \mathrm{~N}_{2}$ or air above liquid mercury contained in a glass bottle at precisely controlled flow rates using a mass flow controller (MKS Mass-Flow Controller, MKS Instruments, Inc.). The bottle resided in a water-filled beaker with the bath temperature held constant at $40^{\circ} \mathrm{C}$. To minimize mercury condensation, the tubing connecting the $\mathrm{Hg}$ feed bottle to the entrance of the furnace was wrapped with heating tape (Type 45500, Thermolyne), and set at $80^{\circ} \mathrm{C}$. The carrier gases, either $\mathrm{N}_{2}, \mathrm{CO}_{2}$, or gas mixtures of $\mathrm{O}_{2}, \mathrm{~N}_{2}$ and $\mathrm{CO}_{2}$, and other constituents, including $\mathrm{H}_{2} \mathrm{O}, \mathrm{HCl}\left(2000 \mathrm{ppm}-\mathrm{N}_{2}\right.$, Wright Bothers) and $\mathrm{NO}\left(5000 \mathrm{ppm}-\mathrm{N}_{2}\right.$, Airgas), were introduced into the reactor via other inlet manifolds using mass flow controllers (MKS Mass-Flow Controller, MKS Instruments, Inc.). Water vapor $\left(\mathrm{H}_{2} \mathrm{O}\right)$ was introduced into the reactor by bubbling $\mathrm{N}_{2}$ or $\mathrm{CO}_{2}$ through milli-Q water. The flow rates of $\mathrm{N}_{2}$ or $\mathrm{CO}_{2}$ were calibrated to establish the desired water vapor concentrations at the inlet of the reactor. The total flow rate through the reactor was $2.0 \mathrm{lpm}$, resulting in the residence time of $2 \mathrm{~s}$ inside the reactor at $800{ }^{\circ} \mathrm{C}$. At the exit of the system, a mercury sampling train was connected downstream of the tubular reactor to determine oxidized and elemental mercury concentrations.

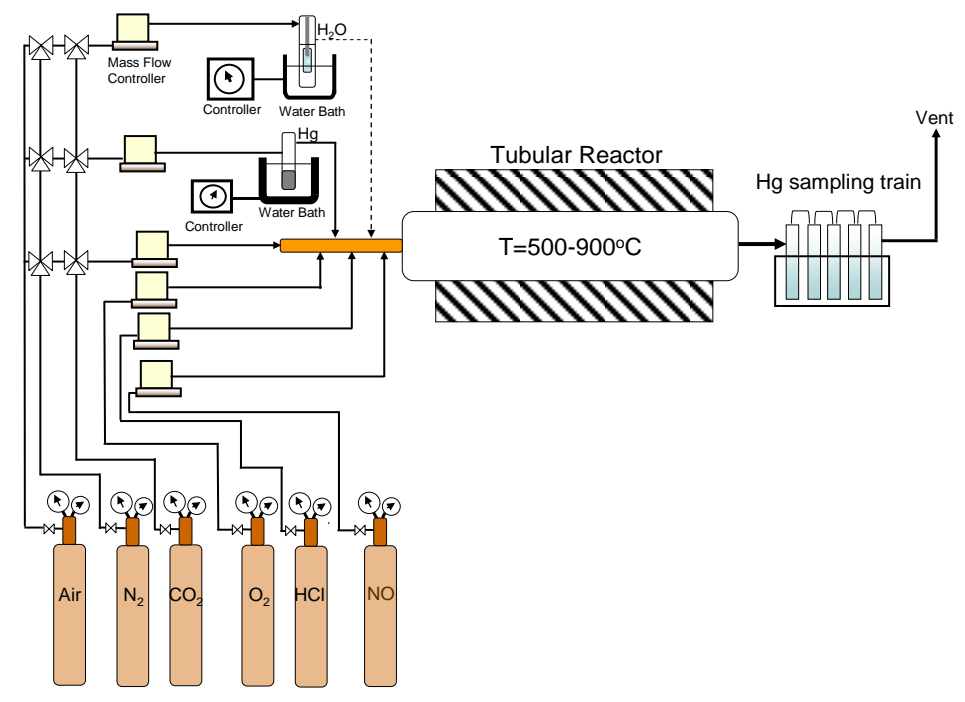

Fig. 1. Schematics of the experimental setup.

\subsection{Mercury Measurement}

The sampling train and technique used for gaseous mercury measurement was based on the method developed by Hedrick et al. (2001) [25]. The sampling train consisted of the following five impinger solutions: two impingers of $1.0 \mathrm{M}$ tris-buffer and EDTA for capture of oxidized mercury, one impinger of $10 \%$ hydrogen peroxide and $2 \%$ nitric acid for oxidizing and capture of elemental mercury, and two impingers of $0.05 \mathrm{M}$ potassium iodide and $2 \%$ hydrochloric acid for capture of elemental mercury. The impinger solutions were analyzed by inductively coupled plasma mass spectrometry (ICP-MS) to determine the elemental and oxidized fractions of mercury in the exhaust gas. Due to the tendency of mercury to adsorb, extra precaution was exercised. To prevent cross-contamination between experimental runs, the reactor and all impingers were acid cleaned. The reactor was purged with particle-free carrier gases at the furnace temperature of $1100^{\circ} \mathrm{C}$ for 30 min before every run. The baseline mercury concentration was periodically verified during each set of experiments. At least four measurements were averaged for each run and the results are reported with standard deviation of all measurements. Since mercury was introduced as $\mathrm{Hg}^{0}$, the extent of $\mathrm{Hg}$ oxidation was calculated as follows: 


$$
H g^{0} \text { oxidation }(\%)=\frac{\left\{\left[\mathrm{Hg}^{0}\right]_{w / o ~ H C l}-\left[\mathrm{Hg}^{0}\right]_{w / H C l}\right\}}{\left[\mathrm{Hg}^{0}\right]_{w / o H C l}} * 100
$$

\section{Results and Discussion}

The study evaluated the effects of flue gas constituents associated with oxy-coal combustion in postcombustion $\mathrm{Hg}$-oxidation by $\mathrm{HCl}$. The first part of this section discusses the influence of carrier gas on the extent of Hg-oxidation. The second and third parts focus on understanding the roles of moisture and NO on the oxidation. In the last part, the combined effects of carrier gases, moisture and $\mathrm{NO}$ on $\mathrm{Hg}$-oxidation are discussed. It should be noted that no $\mathrm{Hg}$-oxidation was observed in the absence of $\mathrm{HCl}$ for all conditions investigated in this study, and the measured $\mathrm{Hg}^{0}$ concentrations for each condition without adding $\mathrm{HCl}$ were used as a baseline to determine the extent of $\mathrm{Hg}$-oxidation.

\subsection{Role of Carrier Gas in Hg-oxidation}

The first set of experiments was conducted to evaluate the effects of carrier gases on $\mathrm{Hg}$-oxidation. The gas mixtures examined in the study, including $10 \% \mathrm{O}_{2}-90 \% \mathrm{CO}_{2}, 10 \% \mathrm{O}_{2}-90 \% \mathrm{~N}_{2}$, and $10 \% \mathrm{O}_{2}-14 \% \mathrm{CO}_{2}-76 \% \mathrm{~N}_{2}$, were chosen to mimic flue gas constituents that would be in oxy-coal and conventional (coal-air) combustion. Pure $\mathrm{CO}_{2}$, pure $\mathrm{N}_{2}$ and air were also studied for comparison. The extents of mercury oxidation in different carrier gases at $\mathrm{HCl}$ concentration of $100 \mathrm{ppm}_{\mathrm{v}}$ are shown in Fig. 2. This $\mathrm{HCl}$ concentration represented the concentration in a typical combustion of bituminous and sub-bituminous coal with medium chlorine content $[27,28]$. Our experimental results indicated that carrier gases evaluated in this study had significant effects on $\mathrm{Hg}$-oxidation. The extent of Hg-oxidation, when it occurred at flue gas temperature of $800^{\circ} \mathrm{C}$, was highest $(32 \%)$ when air was a carrier gas and lowest $(8 \%)$ when $\mathrm{CO}_{2}$ was a carrier gas. No data were shown when $\mathrm{N}_{2}$ was a carrier gas since no $\mathrm{Hg}$-oxidation was observed for temperature evaluated in this set of experiments. For gas mixtures with the same $\mathrm{O}_{2}$ concentration, the extent of $\mathrm{Hg}$-oxidation was highest $(28 \%)$ in a $10 \% \mathrm{O}_{2}-90 \% \mathrm{CO}_{2}$ gas mixture, followed by a $10 \% \mathrm{O}_{2-}$ $14 \% \mathrm{CO}_{2}-76 \% \mathrm{~N}_{2}$ gas mixture $(26 \%)$, and a $10 \% \mathrm{O}_{2}-90 \% \mathrm{~N}_{2}$ mixture $(25 \%)$. The extent of $\mathrm{Hg}$-oxidation increased with temperature for all carrier gases investigated in this study.

The differences in $\mathrm{Hg}$-oxidation were attributed to the concentrations of the reactive $\mathrm{Cl}$-species generating in air, $\mathrm{N}_{2}, \mathrm{CO}_{2}$ or gas mixtures. Since $\mathrm{HCl}$ has been at the reduced state and it cannot directly oxidize $\mathrm{Hg}^{0}$ [13], $\mathrm{Hg}$-oxidation must occur via the reactive chlorine intermediates derived from $\mathrm{HCl}$. Previous research has established the pathways for $\mathrm{Hg}^{0}$ oxidation, reaction 1-8 shown in Table 2 [15, 16, 19]. The reaction rate constant, $k$, suggested that only $\mathrm{Cl}$ can initiate $\mathrm{Hg}^{0}$ oxidation at a substantial rate, shown in reaction 1, Table 2. Roesler et al. (1995) and Mueller et al. (1998) reported that $\mathrm{HCl}$ can dissociate to $\mathrm{Cl}$ in the presence of oxygen $(\mathrm{O})$, hydrogen $(\mathrm{H})$ or hydroxyl $(\mathrm{OH})$ radicals, shown in reactions 9,10 and 11, Table $4.2[29,30]$. Even though $\mathrm{HCl}$ dissociation via attack by $\mathrm{OH}$ radicals (reaction 11) would be the primary pathway for releasing $\mathrm{Cl}$ atoms into flue gas, for carrier gases investigated in this study, $\mathrm{O}$ radicals are the species initiating $\mathrm{HCl}$ dissociation reactions, and they must derive from $\mathrm{O}_{2}$ or $\mathrm{CO}_{2}$. The highest $\mathrm{Hg}$ oxidation found in air, which contained the highest volume fraction of $\mathrm{O}_{2}\left(\mathrm{air}, 21 \% \mathrm{O}_{2}-79 \% \mathrm{~N}_{2}\right.$ ), and the lowest found in pure $\mathrm{CO}_{2}$, indicated that $\mathrm{O}_{2}$ was the primary source of $\mathrm{O}$. With the same volume fraction of $\mathrm{O}_{2}$, slight differences in $\mathrm{Hg}$-oxidation among the gas mixtures further verify that the volume fraction of $\mathrm{O}_{2}$ controls the pool of $\mathrm{Cl}$ that is available to react with $\mathrm{Hg}^{0}$. These results are in agreement with Agarwal and Stenger (2006). Little effect of $\mathrm{CO}_{2}$ on $\mathrm{Hg}$-oxidation was observed in simulated flue gas of conventional coal combustion [31]. It should be also noted that $\mathrm{N}_{2}$ did not assist dissociation of $\mathrm{HCl}$ as no Hg-oxidation was observed when $\mathrm{N}_{2}$ was a carrier gas.

In oxy-coal combustion, concentration of $\mathrm{O}_{2}$ would be higher than that in conventional coal combustion flue gas to maintain the same boiler temperature or to increase boiler thermal efficiency [7]. Our experimental results suggested that Hg-oxidation would be higher than that found in conventional coal combustion systems. 


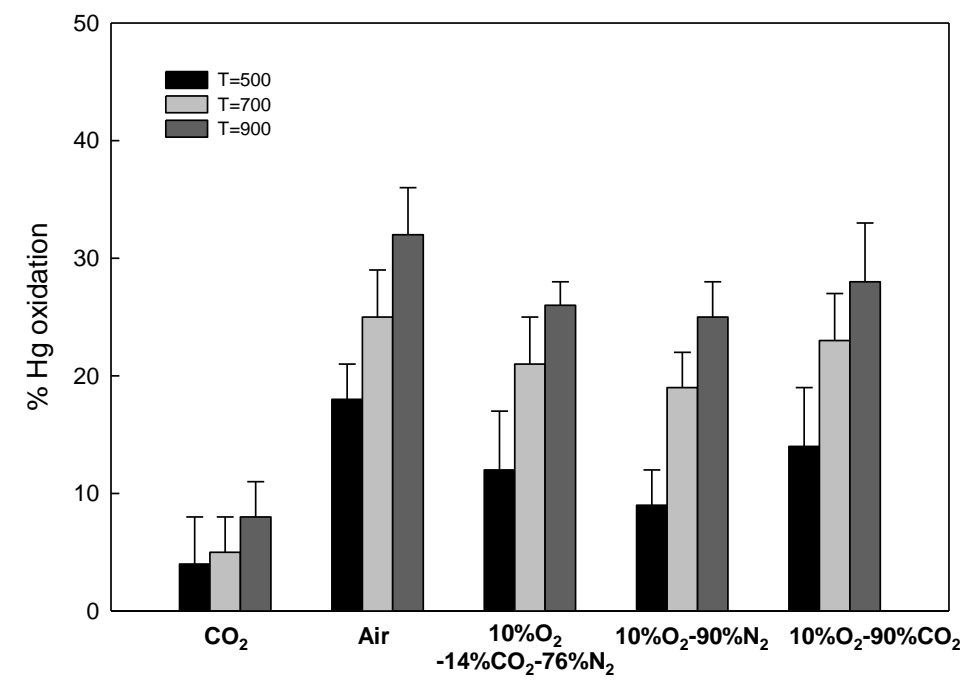

Fig. 2. Effects of carrier gas on $\mathrm{Hg}$-oxidation by $100 \mathrm{ppm}_{\mathrm{v}} \mathrm{HCl}$.

Table 2. The pathways for $\mathrm{Hg}^{0}$ oxidation.

\begin{tabular}{|c|c|c|c|c|c|c|}
\hline Reaction & \multicolumn{2}{|c|}{ Reactions } & A & $\beta$ & $\mathrm{E}_{\mathrm{a}}$ & Ref. \\
\hline 1 & $\mathrm{Hg}+\mathrm{Cl}+\mathrm{M}$ & $\mathrm{HgCl}+\mathrm{M}$ & $2.4 \times 10^{8}$ & 1.4 & -14.4 & 20 \\
\hline 2 & $\mathrm{Hg}+\mathrm{Cl}_{2}$ & $\mathrm{HgCl}+\mathrm{Cl}$ & $1.39 \times 10^{14}$ & 0.0 & 34.0 & 20 \\
\hline 3 & $\mathrm{HgCl}+\mathrm{Cl}_{2}$ & $\mathrm{HgCl}_{2}+\mathrm{M}$ & $1.39 \times 10^{14}$ & 0.0 & 1.0 & 20 \\
\hline 4 & $\mathrm{HoCl}+\mathrm{Cl}+\mathrm{M}$ & $\mathrm{HgCl}_{2}+\mathrm{M}$ & $2.19 \times 10^{18}$ & 0.0 & 3.1 & 20 \\
\hline 5 & $\mathrm{Hg}+\mathrm{HOCl}$ & $\mathrm{HgCl}+\mathrm{OH}$ & $4.27 \times 10^{13}$ & 0.0 & 19.0 & 20 \\
\hline 6 & $\mathrm{Hg}+\mathrm{HCl}$ & $\mathrm{HgCl}+\mathrm{H}$ & $4.94 \times 10^{14}$ & 0.0 & 79.3 & 20 \\
\hline 7 & $\mathrm{HoCl}+\mathrm{HCl}$ & $\mathrm{HgCl}_{2}+\mathrm{H}$ & $4.94 \times 10^{14}$ & 0.0 & 21.5 & 20 \\
\hline 8 & $\mathrm{HgCl}+\mathrm{HOCl}$ & $\mathrm{HgCl}_{2}+\mathrm{OH}$ & $4.27 \times 10^{13}$ & 0.0 & 1.0 & 20 \\
\hline 9 & $\mathrm{HCl}+\mathrm{O}$ & $\mathrm{OH}+\mathrm{Cl}$ & $3.37 \times 10^{3}$ & 0.0 & 3.51 & 27,28 \\
\hline 10 & $\mathrm{HCl}+\mathrm{H}$ & $\mathrm{H}_{2}+\mathrm{Cl}$ & $1.69 \times 10^{13}$ & 1.65 & 4.14 & 27,28 \\
\hline 11 & $\mathrm{HCl}+\mathrm{OH}$ & $\mathrm{H}_{2} \mathrm{O}+\mathrm{Cl}$ & $2.71 \times 10^{7}$ & 2.87 & -0.22 & 27,28 \\
\hline 12 & $\mathrm{NO}+\mathrm{O}+\mathrm{M}$ & $\mathrm{NO}_{2}+\mathrm{M}$ & $4.72 \times 10^{24}$ & -2.87 & 1.55 & 28,35 \\
\hline 13 & $\mathrm{NO}+\mathrm{H}+\mathrm{M}$ & $\mathrm{HNO}+\mathrm{M}$ & $5.0 \times 10^{19}$ & -1.32 & 0.74 & 28,35 \\
\hline 14 & $\mathrm{NO}+\mathrm{OH}+\mathrm{M}$ & $\mathrm{HONO}+\mathrm{M}$ & $5.08 \times 10^{23}$ & -2.51 & -0.007 & 28,35 \\
\hline 15 & $\mathrm{HONO}+\mathrm{Cl}$ & $\mathrm{HCl}+\mathrm{NO}_{2}$ & $5.00 \times 10^{13}$ & 0.0 & 0.0 & 28,35 \\
\hline
\end{tabular}

Note: $k=A T^{\beta} \exp \left(-E_{a} / R T\right) ; M=$ any molecules acting as a third-body collision

\subsection{Role of Moisture in Hg-oxidation}

Several studies reported that $\mathrm{H}_{2} \mathrm{O}$ is an important factor influencing the degree of $\mathrm{Hg}$ oxidation [19, 32]. In conventional coal combustion flue gas, moisture content ranges between 7 to $15 \%$ [25, 33]. Depending on flue gas recycled ratio, moisture content in oxy-coal combustion flue gas would range between that in conventional flue gas and that in the flue gas of coal combustion in pure oxygen (27\%) (Sandia National Laboratories, 2009) [34]. In this set of experiments, the moisture content, ranging from $7 \%$ to $20 \%$, was chosen to correspond to that in conventional and oxy-coal combustions. The effects of moisture on $\mathrm{Hg}-$ oxidation by $100 \mathrm{ppm}_{\mathrm{v}} \mathrm{HCl}$ in different carrier gases are reported in Fig. 3. For all gas mixtures and air, the extent of the oxidation drastically decreased in the presence of $\mathrm{H}_{2} \mathrm{O}$; however, the effect of moisture content on the oxidation was not significant. For example, when air was a carrier gas, the extent of $\mathrm{Hg}$ oxidation decreased from $32 \%$ without $\mathrm{H}_{2} \mathrm{O}$ present to $25 \%$ with $7 \% \mathrm{H}_{2} \mathrm{O}$ added, but it decreased to $18 \%$ 
when moisture content increased from $7 \%$ to $20 \%$. The decrease in $\mathrm{Hg}$-oxidation was attributed to the abundant supply of $\mathrm{OH}$ radicals that dissociated from $\mathrm{H}_{2} \mathrm{O}$ and competed with $\mathrm{Hg}^{0}$ for $\mathrm{Cl}$ radicals to form less reactive chlorinating species, such as $\mathrm{HOCl}$. In addition, high concentration of $\mathrm{OH}$ radicals substantially increased reduction rate of $\mathrm{HgCl}$ to form $\mathrm{Hg}^{0}$ and $\mathrm{HOCl}$-thus, lowering $\mathrm{Hg}$-oxidation [19]. In comparing gas mixtures and air, the effects of moisture in $\mathrm{Hg}$-oxidation were not found significantly different. The extents of $\mathrm{Hg}$-oxidation at $20 \% \mathrm{H}_{2} \mathrm{O}$ were $18 \%$ for air, ranging between $15 \%-16 \%$ for gas mixtures. This indicated that the impact of $\mathrm{H}_{2} \mathrm{O}$ on $\mathrm{Hg}$-oxidation outweighed that of $\mathrm{O}_{2}$ concentrations demonstrated in Set I experiments.

When $\mathrm{CO}_{2}$ and $\mathrm{N}_{2}$ were carrier gases, in contrast to the gas mixtures, the presence of $\mathrm{H}_{2} \mathrm{O}$ promoted $\mathrm{Hg}$-oxidation at low moisture content $(7 \%)$ and suppressed the oxidation when moisture content increased $(15 \%$ and $20 \%)$. The former result suggested that $\mathrm{OH}$ radicals dissociated from $\mathrm{H}_{2} \mathrm{O}$ initiated the formation of $\mathrm{Cl}$ radicals from $\mathrm{HCl}$ (shown in reaction 11, Table 4.2), which subsequently provided the channel towards $\mathrm{Hg}$-oxidation. At high moisture content, the inhibitory effect on $\mathrm{Hg}$-oxidation indicated that $\mathrm{Cl}$ radicals would mostly be consumed by $\mathrm{OH}$ radicals to form their respective oxidized products, or the reduction rate $\mathrm{HgCl}$ via attack by $\mathrm{OH}$ radicals substantially increased and it became a significant competing mechanism on $\mathrm{Hg}$-oxidation. The results from this set of experiments clearly indicated the importance of flue gas constituents and their concentrations on Hg-oxidation.

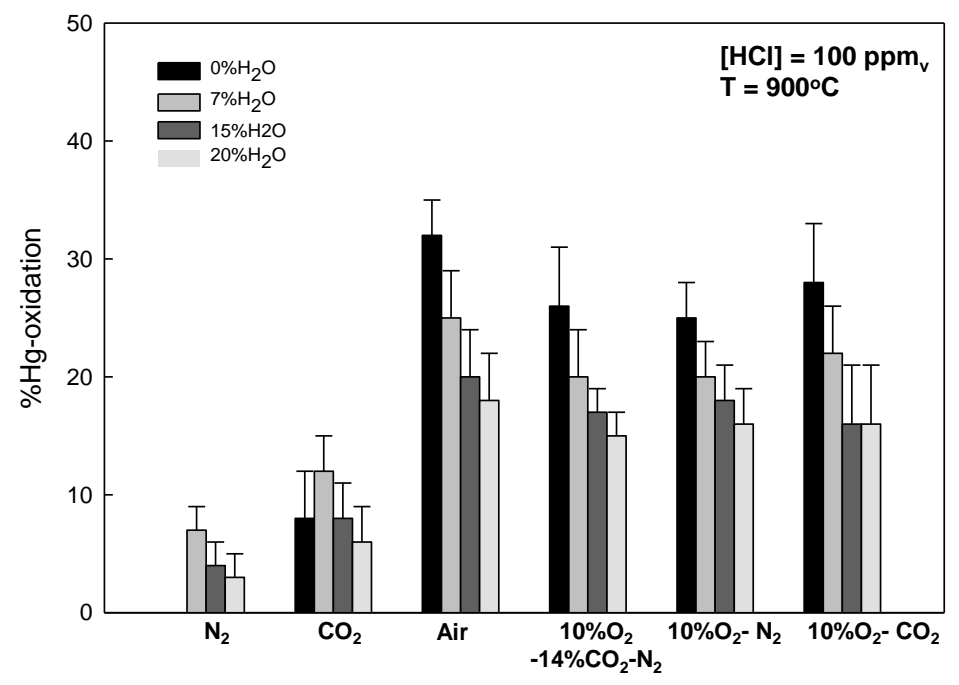

Fig. 3. Effects of $\mathrm{H}_{2} \mathrm{O}$ on $\mathrm{Hg}$-oxidation by $100 \mathrm{ppm}_{\mathrm{v}} \mathrm{HCl}$ in different carrier gas.

\subsection{Role of $\mathrm{NO}$ on $\mathrm{Hg}$ Oxidation}

Besides moisture, the presence of $\mathrm{NO}$ in flue gas was reported to exert a strong impact on Hg-oxidation $[19,35]$. Due to the absence of $\mathrm{N}_{2}$ and a re-burn effect of the recycled flue gas in oxy-coal combustion, concentration of NO could be decreased to only $14 \%$ of conventional coal combustion [6]. In this set of experiments, the NO concentrations, ranging from 40 to $400 \mathrm{ppm}_{\mathrm{v}}$, were selected to correspond to that in conventional and oxy-coal combustions. The effects of $\mathrm{NO}$ on $\mathrm{Hg}$-oxidation by $100 \mathrm{ppm}_{\mathrm{v}} \mathrm{HCl}$ in different carrier gases are reported in Fig. 4. No data were shown for $\mathrm{N}_{2}$, since no $\mathrm{Hg}$-oxidation was observed for all concentrations of $\mathrm{NO}$ evaluated in this set of experiments. It should be noted that $\mathrm{Hg}$-oxidation by $\mathrm{NO}$ in the absence of $\mathrm{HCl}$ was negligible. The presence of $\mathrm{NO}$ strongly suppressed $\mathrm{Hg}$-oxidation by $\mathrm{HCl}$ for all carrier gases. The effect was more pronounced when $\mathrm{CO}_{2}$ was a carrier gas--the extent of Hg-oxidation was completely inhibited in the presence of NO. For gas mixtures with the same $\mathrm{O}_{2}$ concentration, no $\mathrm{Hg}$ oxidation was observed at NO concentrations above $200 \mathrm{ppm}_{\mathrm{v}}$. When air was a carrier gas, the extent of the oxidation was completely suppressed at $\mathrm{NO}$ concentration of $400 \mathrm{ppm}_{\mathrm{v}}$. The inhibitory effects were attributed to the consumption of $\mathrm{O}, \mathrm{H}$, and $\mathrm{OH}$ by NO. As shown in reaction 12, 13 and 14, Table 4.2, $\mathrm{NO}$ competed with $\mathrm{HCl}$ for $\mathrm{O}, \mathrm{H}, \mathrm{OH}[36]$, and subsequently impeded the formation of $\mathrm{Cl}$ radicals for $\mathrm{Hg}$ oxidation. In pure $\mathrm{CO}_{2}, \mathrm{O}$ radicals were much less available than those in gas mixtures. As a result, the complete inhibitory effect was exhibited at lower $\mathrm{NO}$ concentrations. When air was a carrier gas, $\mathrm{O}_{2}$ 
concentration was highest $(21 \%)$ and presumably so was the concentrations of radicals, specifically O. As a result, the complete inhibitory effect exhibited at higher NO concentration.

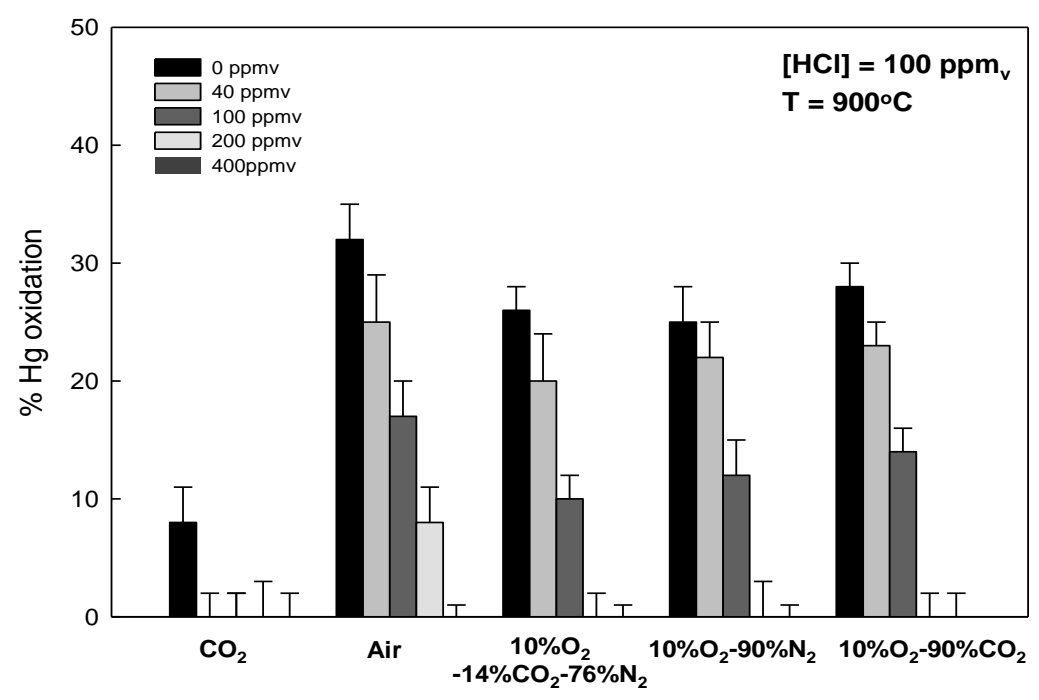

Fig. 4. Effects of $\mathrm{NO}$ on $\mathrm{Hg}$-oxidation by $100 \mathrm{ppm}_{\mathrm{v}} \mathrm{HCl}$ in different carrier gas.

\subsection{Combined Effect of $\mathrm{H}_{2} \mathrm{O}$ and NO}

Set 4 experiments were designed to evaluate the extent of $\mathrm{Hg}$-oxidation when moisture and $\mathrm{NO}$ were present together. The selected moisture content was $7 \%$ and $20 \%$ by volume and concentrations of NO were 40 and 100 ppm $_{\mathrm{v}}$. Experimental results are reported in Fig. 5 (a) and Fig. 5 (b). For all gas mixtures, air and $\mathrm{CO}_{2}$, the presence of $\mathrm{H}_{2} \mathrm{O}$ and $\mathrm{NO}$ together exhibited stronger inhibitory effects on Hg-oxidation than those found when the individual compounds were present alone. For example, when air was a carrier gas, the extent of $\mathrm{Hg}$-oxidation decreased from $32 \%$ without $\mathrm{H}_{2} \mathrm{O}$ present to $25 \%$ with $7 \% \mathrm{H}_{2} \mathrm{O}$ added, it decreased from $32 \%$ without $\mathrm{H}_{2} \mathrm{O}$ present to $25 \%$ when $40 \mathrm{ppm}_{\mathrm{v}} \mathrm{NO}$ added, and when $7 \% \mathrm{H}_{2} \mathrm{O}$ and 40 $\mathrm{ppm}_{\mathrm{v}} \mathrm{NO}$ were present together, only $12 \% \mathrm{Hg}$-oxidation was observed. As previously described, the presence of $\mathrm{H}_{2} \mathrm{O}$ and $\mathrm{NO}$ individually affects $\mathrm{Hg}$-oxidation via controlling the pool of radicals, including $\mathrm{Cl}$, $\mathrm{H}, \mathrm{OH}$, and $\mathrm{O}$. This synergistic effect indicated that the availability of radicals decreased when $\mathrm{H}_{2} \mathrm{O}$ and NO were together. Previous researchers had established that HONO formed when nitrogen species and $\mathrm{OH}$ radicals present together, shown in reaction 14, Table 2 [28,37]. With no activation energy required, $\mathrm{HONO}$ could directly scavenge $\mathrm{Cl}$ radicals to form $\mathrm{HCl}$ and $\mathrm{H}_{2} \mathrm{O}$, shown in reaction 15 in Table 4.2 [38,39]. This resulted in less $\mathrm{Cl}$ available for $\mathrm{Hg}$-oxidation. In comparing all gas mixtures and air, the effects of coupling moisture and $\mathrm{NO}$ in $\mathrm{Hg}$-oxidation were not found significantly different, $6 \%$ for air and ranging between 3\% to 4\% for gas mixtures at 7\% moisture content and $100 \mathrm{ppm}_{\mathrm{v}} \mathrm{NO}$. This indicated that the impact of $\mathrm{NO}$ and $\mathrm{H}_{2} \mathrm{O}$ on $\mathrm{Hg}$-oxidation exceeded that of the carrier gases demonstrated in Set I experiments. 

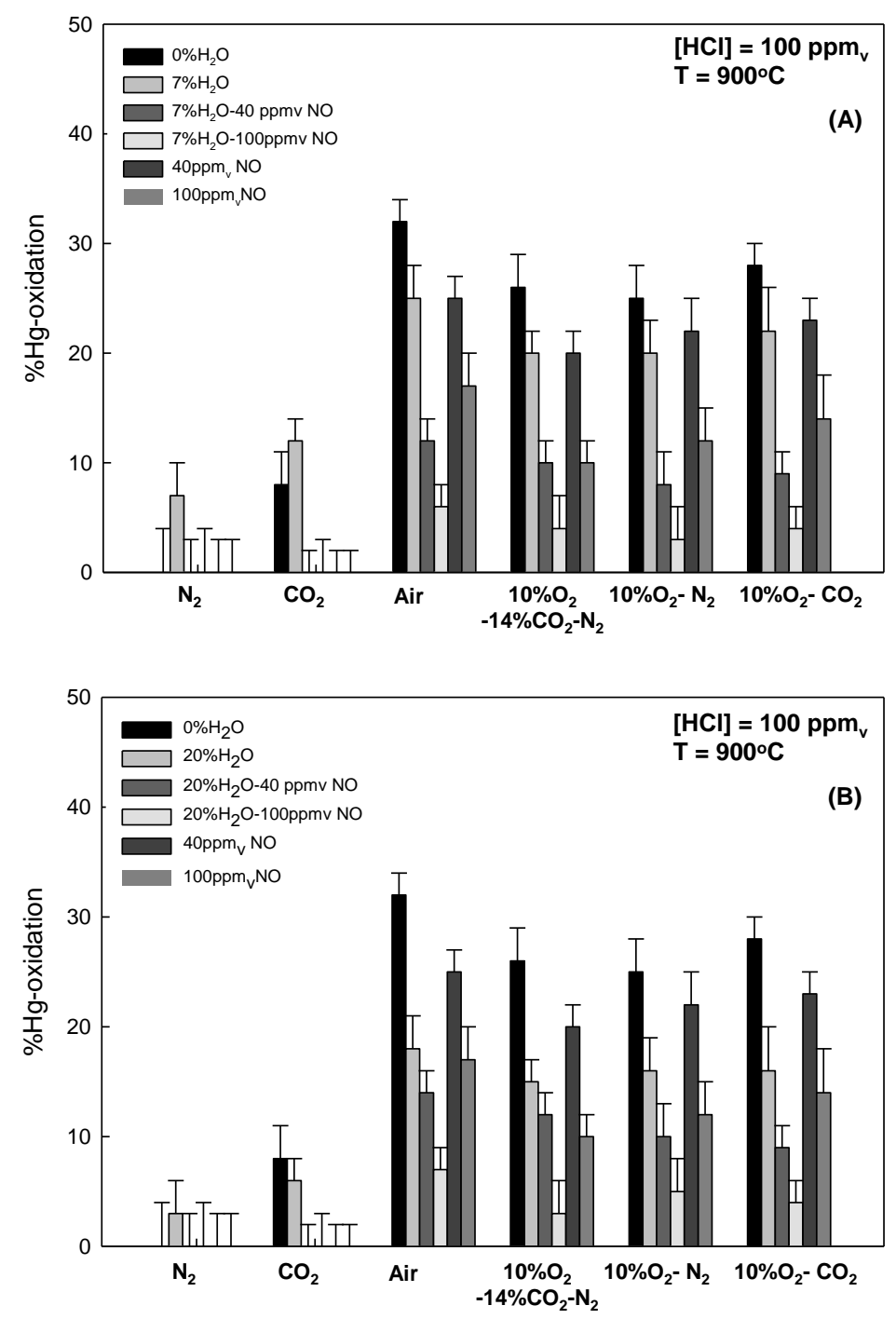

Fig. 5. The combined effect of $\mathrm{NO}$ and $\mathrm{H}_{2} \mathrm{O}$ on $\mathrm{Hg}$-oxidation by $\mathrm{HCl}$ in different carrier gas. (a) $\mathrm{Hg}$ oxidation at $7 \% \mathrm{H}_{2} \mathrm{O}$ with 40 and $100 \mathrm{ppm}_{\mathrm{v}} \mathrm{NO}$, (b) Hg-oxidation at $20 \% \mathrm{H}_{2} \mathrm{O}$ with 40 and $100 \mathrm{ppm}_{\mathrm{v}} \mathrm{NO}$.

In comparing the influence of moisture content on the combined effects of $\mathrm{H}_{2} \mathrm{O}$ and $\mathrm{NO}$, the extents of $\mathrm{Hg}$-oxidation slightly decreased when moisture content increased from $7 \%$ to $20 \%$ for all carrier gases. This indicated that $\mathrm{OH}$ radicals that dissociated from $\mathrm{H} 2 \mathrm{O}$ were abundant and that increasing moisture content did not significantly affect the pool of radicals, specifically $\mathrm{Cl}$, and subsequently Hg-oxidation. In oxy-coal combustion, moisture content would be higher than that in conventional coal combustion, while concentration of $\mathrm{NO}$ would be lower than that in conventional coal combustion. Our experimental results suggested that $\mathrm{Hg}$-oxidation in oxy-coal combustion would be higher than that found in conventional coal combustion systems.

\section{Conclusion}

This study explored the potential impact of oxy-coal combustion on homogeneous mercury oxidation. The experiments were systematically designed to identify the influence of each constituent and its concentration. Our experimental results demonstrated that $\mathrm{CO}_{2}$ assisted $\mathrm{Hg}$-oxidation by $\mathrm{HCl}$; however, its influence was outweighed by the presence of $\mathrm{O}_{2} . \mathrm{N}_{2}$ alone did not participate in the oxidation of $\mathrm{Hg}$. The presence of $\mathrm{NO}$ and $\mathrm{H}_{2} \mathrm{O}$ inhibited $\mathrm{Hg}$-oxidation for all carrier gases investigated in this study. The inhibitory effects depended strongly on the concentration of NO, but not on moisture content. For all carrier gases, synergistic inhibitory effects were demonstrated when $\mathrm{NO}$ and $\mathrm{H}_{2} \mathrm{O}$ were present together. These results were attributed to the impact of flue gas constituents on the pool of $\mathrm{Cl}$ that is available to react with $\mathrm{Hg}^{0}$. 
Our experimental findings suggested that in oxy-coal combustion, while $\mathrm{Hg}$-oxidation would not be critically affected by highly concentrated $\mathrm{CO}_{2}$ in the flue gas, it would be impacted by other flue gas constituents, such as $\mathrm{NO}$ and $\mathrm{H}_{2} \mathrm{O}$, and their concentrations, which are influenced by oxy-coal combustion.

\section{References}

[1] U. Desideri, and A. Paolucci, "Performance modeling of a carbon dioxide removal system for power plants," Energy Conversion and Management, vol. 40, pp. 1899-1915, 1999.

[2] R. D. Doctor, J. C. Molburg, and P. R. Thimmapuram, "Oxygen Blown Gasification Combined Cycle: Carbon dioxide recovery, transport and disposal," Energy Conversion Management, vol. 38, pp. 575-580, 1997.

[3] B. Hektor, "Cost effectiveness of measures for the reduction of net accumulation of carbon dioxide in the atmosphere," Biomass and Bioenergy, vol. 15, pp. 229-309, 1998.

[4] C. M. White, et al., "Separation and Capture of $\mathrm{CO}_{2}$ from Large Stationary Sources and Sequestration in Geological Formations - Coalbeds and Deep Saline Aquifers," Journal of the Air and Waste Management Association, vol. 53, pp. 645-715, 2003.

[5] H. Liu, et al., "Sulfation Behavior of Limestone under High $\mathrm{CO}_{2}$ Concentration in $\mathrm{O}_{2} / \mathrm{CO}_{2}$ coal combustion," Fuel, vol. 79, pp. 945-953, 2000.

[6] H. Liu, and K. Okazaki, "Simultaneous Easy $\mathrm{CO}_{2}$ Recovery and Drastic Reduction of $\mathrm{SO}_{\mathrm{x}}$ and $\mathrm{NO}_{\mathrm{x}}$ in $\mathrm{O}_{2} / \mathrm{CO}_{2}$ Coal Combustion with Heat Recirculation," Fuel, vol. 82, pp. 1427-1436, 2003.

[7] A. Suriyawong, et al., "Submicrometer Partical Formation and Mercury Speciation under $\mathrm{O}_{2}-\mathrm{CO}_{2} \mathrm{Coal}$ Combustion," Energy \& Fuels, vol. 20, no. 6, pp. 2357-2363, 2006.

[8] A. Suriyawong, C. J. J. Hogan, and P. Biswas, "Charged Fraction and Electrostatic Capture of Ultrafine and Submicrometer Particles Formed under $\mathrm{O}_{2}-\mathrm{CO}_{2}$ Coal Combustion," Fuel, vol. 87, pp. 673-682, 2008.

[9] E. Croiset, and K. V. Thambimuthu, " $\mathrm{NO}_{x}$ and $\mathrm{SO}_{2}$ emissions from $\mathrm{O}-2 / \mathrm{CO}_{2}$ recycle coal combustion," Fuel, vol. 80, no. 14, pp. 2117-2121, 2001.

[10] EPA, "National Emission Inventory for Hazadous air pollutants," Office of Air Quality Planning and Standards and Office of Research and Development, U.S. Environmental Protection Agency, 1999.

[11] C. Senior, et al., "Gas Phase Transformations of Mercury in Coal-fired Power Plants," Fuel Processing Technology, vol. 63, no. 2-3, pp. 197-213, 2000.

[12] K. Liu, et al., "Study of Mercury Removal in FBC Systems Fired with High-chlorine Coals," Combustion Science and Technology, vol. 164, pp. 145-162, 2001.

[13] Y. Zhuang, et al., "Impact of Calcium Chloride Addition on Mercury Transformations and Control in Coal Flue Gas," Fuel, vol 86, pp. 2351-2359, 2007.

[14] Y. Cao, et al., "Impact of Coal Chlorine on Mercury Speciation and Emission from a 100-MW Utility Boiler with Cold-side Electrostatic Precipitators and Low-NOx Burners," Energy \& Fuels, vol. 19, no. 3, pp. 842-854, 2005.

[15] R. N. Sliger, J. C. Kramlich, and N. M. Marinov, "Towards the development of a chemical kinetic model for the homogeneous oxidation of mercury by chlorine species," Fuel Processing Tecbnology, vol. 65, pp. 423-438, 2000.

[16] Y. Zhao, et al., "Effects of Sulfur Dioxide and Nitric Oxide on Mercury Oxidation and Reduction under Homogeneous Conditions," Journal of the Air \& Waste Management Association, vol. 56, pp 628635, 2006.

[17] C. G. Zheng, et al., "Kinetic mechanism studies on reactions of mercury and oxidizing species in coal combustion," Fuel, vol. 84, no.10, pp. 1215-1220, 2005.

[18] J. R. Edwards, R. K. Srivastava, and J. D. Kilgroe, "Study of Gas-phase Mercury Speciation using Detailed Chemical Kinetics," Journal of Air and Waste Management Association, vol. 51, pp. 869-877, 2001.

[19] S. Niksa, J. J. Helble, and N. Fujiwara, "Kinetic modeling of homogeneous mercury oxidation: The importance of $\mathrm{NO}$ and $\mathrm{H}_{2} \mathrm{O}$ in predicting oxidation in coal-derived systems," Environmental Science \& Technology, vol. 35, no. 18, pp. 3701-3706, 2001.

[20] S. Niksa, et al., "A mechanism for mercury oxidation in coal-derived exhausts," Journal of the Air \& Waste Management Association, vol. 52, no. 8, pp. 894-901, 2002.

[21] C. L Senior, J. J. Helble, and A. F. Sarofim, "Emissions of mercury, trace elements, and fine particles from stationary combustion sources," Fuel Processing Technology, vol. 65, pp. 263-288, 2000. 
[22] C. L. Senior, et al., "Gas-phase transformations of mercury in coal-fired power plants," Fuel Processing Technology, vol. 63, no. 2-3, pp. 197-213, 2000.

[23] Y. Zhuang, et al., "Kinetic transformation of mercury in coal combustion flue gas in a bench-scale entrained-flow reactor," Fuel Processing Technology, vol. 85, no. 6-7, pp. 463-472, 2004.

[24] O.Font, et al., "Fate and abatement of mercury and other trace elements in a coal-fluidised bed oxy combustion pilot plant”, Fuel, vol.95, pp.272-281, 2012.

[25] H. Wang, Y. Duan, and Y. Mao, "Mercury speciation in air-coal and oxy-coal combustion", Cleaner Combustion and Sustainable World-Proceedings of the $7^{\text {th }}$ international Symposium on Coal Combustion, 2013.

[26] E. Hedrick, T. G. Lee, P. Biswas, and Y. Zhuang, "The Development of Iodine Based Impinger Solutions for the Efficient Capture of $\mathrm{Hg} 0 \mathrm{Using}$ Direct Injection Nebulization-Inductively Coupled Plasma Mass Spectrometry Analysis," Environmental Science and Technology, vol. 35, no. 18, pp. 3764-3773, 2001.

[27] Y. Cao, et al., "Investigation of mercury transformation by $\mathrm{HBr}$ addition in a slipstream facility with real flue gas atmospheres of bituminous coal and powder river basin," Energy \& Fuels, vol. 21, no. 5, pp. 2719-2730, 2007.

[28] J. H. Pavlish, et al., "Status review of mercury control options for coal-fired power plants," Fuel Processing Technology, vol. 82, pp. 89-165, 2003.

[29] C. Mueller, P. Kilpinen, and M. Hupa, "Influence of $\mathrm{HCl}$ on the homogeneous reactions of $\mathrm{CO}$ and NO in postcombustion conditions - A kinetic modeling study," Combustion and Flame, vol. 113, no. 4, pp. 579-588, 1998.

[30] J. F. Roesler, R. A. Yetter, and F. L. Dryer, "Kinetic Interactions of $\mathrm{CO}, \mathrm{NO}_{\mathrm{x}}$, and $\mathrm{HCl}$ Emissions in Postcombustion Gases," Combustion and Flame, vol. 100, no. 3, pp. 495-504, 1995.

[31] H. Agarwal, et al., "Effects of $\mathrm{H}_{2} \mathrm{O}, \mathrm{SO}_{2}$, and $\mathrm{NO}$ on Homogeneous $\mathrm{Hg}$ Oxidation by $\mathrm{Cl}_{2}$," Energy \& Fuels, vol. 20, pp. 1068-1075, 2006.

[32] H. Agarwal, et al., "Effects of $\mathrm{H}_{2} \mathrm{O}, \mathrm{SO}_{2}$, and $\mathrm{NO}$ on homogeneous $\mathrm{Hg}$ oxidation by $\mathrm{Cl}-2$," Energy e Fuels, vol. 20, no. 3, pp. 1068-1075, 2006.

[33] A. Suriyawong, et al., "Mercury Capture by Nano-structured Titanium Dioxide Sorbent during Coal Combustion: Lab-scale to Pilot-scale Studies," Aerosol and Air Quality Research, 2009. (accepted).

[34] S. N. Li, Coal Ignition and Devolatilization during Oxy-fuel Coal Combustion with $\mathrm{CO}_{2}$ Recirculation, 2009. Available from: http://www.ca.sandia.gov/.

[35] G. A. Norton, et al., "Heterogeneous oxidation of mercury in simulated post combustion conditions," Fuel, vol. 82, no. 2, pp. 107-116, 2003.

[36] M. T. Allen, R. A. Yetter, and F. L. Dryer, "High Pressure Study of Moist/Carbon monoxide/Nitrous Oxide Kinetics," Combustion and Flame, vol. 109, pp. 449-470, 1997.

[37] A. I. Martinez, and B. K. Deshpande, "Kinetic modeling of H2O2-enhanced oxidation of flue gas elemental mercury," Fuel Processing Technology, vol. 88, no. 10, pp. 982-987, 2007.

[38] M. H. Xu, et al., "Modeling of homogeneous mercury speciation using detailed chemical kinetics," Combustion and Flame, vol. 132, no1-2, pp. 208-218, 2003.

[39] S. P. Sable, W. Jong, and H. Spliethoff, "Combined Homo- and Heterogeneous Model for Mercury Speciation in Pulverized Fuel Combustion Flue Gases," Energy \& Fuels, vol. 22, pp. 321-330, 2008. 
